\title{
Democratisation of Defence Policies and Systems in Slovenia and Montenegro: Developmental and Comparative Aspects
}

\author{
IZTOK PREZELJ, OLIVERA INJAC AND ANJA KOLAK
}

\section{Sciendo}

Politics in Central Europe (ISSN: 1801-3422)

Vol. 16, No. 3

DOI: $10.2478 /$ pce-2020-0032

\begin{abstract}
The democratisation of national defence policies and systems plays a vital role in making any country more democratic. The democratic transition of this sector in Slovenia and Montenegro has experienced a challenging reform process and it is now time for reflection. This paper aims to identify the main characteristics and issues of the democratisation process in the field of national defence in both countries and, by comparing them, to look for key similarities and differences. The paper argues and confirms that the Slovenian and Montenegrin national defence and security systems were initially faced with serious post-socialist democratic deficits, but gradual democratisation then brought drastic improvements to the quality of their democracy. The process of joining NATO and the change from a military threat perception to a non-military threat perception created space for many reforms. Greatest steps forward in democratisation in both countries entailed nominating civilian defence ministers, having a reasonable number of civilian defence experts involved in the military business, establishing working parliamentary monitoring committees, reducing defence budgets and reallocating funding to other sectors. Progress was also observed in reducing the total number of soldiers, establishing a fully professional armed force, assuring that women in the armed forces were properly represented and increasing the deployment of soldiers to foreign stabilisation operations in a sign of becoming security providers.
\end{abstract}

Keywords: democratisation, security sector reforms, security, defence policy, defence system, transition 


\section{Introduction}

Slovenia and Montenegro endured a difficult process of democratisation and transition to a democracy. The area of national defence was no exception. In fact, democratisation was even more important than bringing democracy into several other fields because national defence and security was a cornerstone of the old socialist regimes. The change and greater transparency of this repressive sector has been fundamental for all modern democratic states in Central, Southern and Eastern Europe.

The state's monopoly over the legal use of force and related secrecy are principal characteristics of national security and defence. A change in these characteristics reflects the true level of democratisation of Central, Southern and Eastern European societies. The power of democratic control over the armed forces, police and intelligence services is significant for democratic systems. Failure in this narrow, yet important field could trigger the end of the democratic state or a seemingly endless limbo without any plausible exit. All newly established states arising from former Yugoslavia underwent a slow, complex and painstaking process of democratising their defence and security policies and systems. These policies and systems were becoming democratic at a time of wars within/ between countries, of an economy transitioning to capitalism with all the related uncertainties and legal vacuums, of foreign sanctions etc. The associated uncertainties call for greater academic attention and for lessons to be learnt.

The goal of this paper is to identify the main internal and external characteristics and issues in the democratisation process concerning the field of national defence in Slovenia and Montenegro, two exemplary cases from former Yugoslavia, and to compare them to find any major similarities and differences. Both countries will be investigated with the same indicators, as described below in the argument and related subchapters. We contend that the democratisation process of political systems in Central and South-Eastern Europe has also depended on reforms of national defence and security policies and systems. The Slovenian and Montenegrin national defence and security systems were faced with serious post-socialist democratic deficits, but then gradual democratisation led to drastic improvements in the quality of democracy. The process of joining NATO and the change from a military threat perception to a non-military threat perception created space for many reforms. In both countries, the biggest steps forward in democratisation included nominating civilian defence ministers, having a reasonable number of civilian defence experts involved in the military business, establishing working parliamentary committees to monitor the security sector, reducing defence budgets at a time of non-existing military threats and reallocating funding to other sectors, decreasing the total number of soldiers, establishing a fully professional armed force, assuring that women in the armed forces are properly represented, and 
the increasing deployment of soldiers to foreign stabilisation operations in a sign of becoming security providers.

There is a gap in the literature with respect to comparing democratisation in the defence field in cases like Slovenia and Montenegro. Such knowledge could prove useful for improving understanding of trends in the region and extracting valuable lessons.

This paper is structured as follows. First, it focuses on the concept and practice of security sector reform within the broader democratic transition process. The next section conceptually describes eight indicators of democratisation and compares them with regard to the cases of Slovenia and Montenegro. In the conclusion, we verify our argument and draw the key lessons that arise from the two cases' similarities and differences.

\section{Democratic Transition and National Defence: The Concept and Practice of Security Sector Reform}

The primary transition in the field of national security and defence in Central, Southern and Eastern Europe after the Cold War had come to an end was about changing the perspective on what security means, and for whom. The traditional unidimensional, military and state-centred security was developing into multidimensional security with environmental, economic, criminal, health and other non-military dimensions. The state was no longer the main referent object of security while the individual was emerging as one. This transition from military to people-centred security meant the entire concept of security was in some ways liberalised.

In this context, the term Security Sector Reform (SSR) was first used in 1998 by the British Secretary of State for Development. It soon became a relevant public policy concept for understanding change in the field of security and defence because, as Fluri (2004: 7) argues, it deals with the use of public resources to ensure the security of citizens. SSR is a broader concept than the democratisation of national defence, but can usefully be applied in this paper. A fundamental part of this concept concerns the transition of countries from an authoritarian to a democratic political system. In other words, SSR lies at the heart of democratic transition in the field of national defence. The purpose of this chapter is to present the main ideas pertaining to this concept.

Every state's security sector consists of institutions responsible for dealing with external and internal security threats to the state and its population, such as the armed forces, intelligence services, police service and institutions exercising control (e.g. the government and its ministries, the parliament and its committees). Some authors also include in the security sector the judiciary, paramilitary forces, border guards, coast guards, custom guards and even non-governmental organisations (see Bearne - Oliker - O'Brien - Rathmell 2005: 
1; Schroeder 2010: 9). Defence sector is a narrower concept because it relates only to the armed forces, related intelligence service, ministry of defence and relevant control bodies.

SSR is also an evolving concept. It basically refers to the effective provision of state and human security in the context of democratic governance (Hänggi 2004: 1). A central element of SSR is the individual and his/her security (human security). The OECD defines SSR as the transformation of the security sector's management and operation in a direction more consistent with democratic norms, the rule of law and principles of good governance. This definition highlights two vital elements: the importance of democratic and civilian control over the security sector and the effective functioning of the sector. This means that a crucial challenge is to establish effective security mechanisms that are under sufficient control. SSR is more than just the institutionalisation of laws and practices, it is a lengthy, complex and unpredictable social process. SSR varies greatly from country to country due to their different needs and conditions, while it is also somewhat similar to democracy: they are both permanent processes regarding which no society will ever achieve perfection (Hänggi 2003: 17).

Institutions are a key element of SSR, but institutional focus should be supplemented with a more problem-oriented focus (Edmunds 2004: 60). This means that SSR is also the sum of changes in the ways of thinking and practising security. It involves a series of parallel and directly/indirectly connected reforms in the security sector. The concept places humans in the centre by stressing demilitarisation, depolitisation and stronger civil, democratic and parliamentary control (Hadžić 2004: 11).

A point of departure in the SSR concept is the dysfunctionality of the security sector. This refers to this sector's incapacity to provide security to the state and people in an effective way or to the fact that the sector even constitutes a threat (security deficit). In practice, SSR reduces a security deficit by lowering the democratic deficit (lack of control over the security sector). SSR is therefore a way to achieve the objective of providing security in the setting of effective democratic civilian control. A holistic approach in SSR is therefore about creating effective security institutions, integrating partial reforms in the fields of defence, intelligence, the police and the judiciary, and establishing democratic civil control. The concept merges the operational effectiveness aspect with the democratic governance aspect. Providing both aspects of SSR is a challenge not only for developing post-conflict states in transition, but also for more mature and consolidated democracies (Hänggi 2004: 4-5). SSR is also important for reducing potential pathologies of the security sector like the overconsumption of resources, underinvestment of resources in the security sector, overemphasis on hard or soft security instruments, ineffective democratic control of the sector etc. Such pathologies of the security sector might lead to the reverse process of de-democratisation and even affect economic growth in developing countries (Law 2004: 6). 
Many authors have specified various dimensions of SSR. For example, Kuhlman-Callaghan (2000) identified the following: changes in thinking and acting in the field of security, changes to constitutional and institutional frameworks, democratic civil control over the armed forces, reforms of the armed forces containing a redefinition of their purposes and tasks with associated alterations to the structure, training, equipment, size, and various forms of international security cooperation with higher levels of integration. Bearne Oliker - O'Brien - Rathmell (2005: 1) more specifically identify the following SSR dimensions:

- improving the security sector's effectiveness in implementing security policies;

- state-building;

- improving capacities for civil control over the security sector;

- improving democratic control, especially during the transition from a mono-party to a democratic political system;

- improving the legitimacy of the state and its security sector;

- improving transparency and responsibility in public affairs;

- funding the security sector according to society's capacity; and

- conflict prevention and post-conflict reconstruction with the implementation of peace agreements.

While discussing SSR, Edmunds (2004: 47-49) noted the following dimensions of SSR: democratisation, good governance, economic development, professionalisation, conflict prevention and integration into Western institutions. These dimensions were assessed as follows:

- Democratisation: the security sector can pose an important obstacle to democratisation. This is clearly seen in the politisation of the security sector in terms of political appetites to use that sector for political purposes or the security sector's involvement in politics. In this respect, democratic civil control is a vital aspect of any democratisation process.

- Good governance is about the appropriate and effective provision of public goods to the population (security is an essential public good). Security institutions should be effective and affordable.

- Economic development is easily disturbed by security instability and unpredictability. Both factors stem from the security sector's poor performance. This means that the effective provision of a secure environment can bring developmental benefits.

- Professionalisation concerns improving the capacity of security institutions to effectively carry out what is required by the civil authority. For the armed forces, this means their tasks are precisely defined to ensure a better performance in future challenges. Hadžić (2004: 36) also showed 
that professionalisation is the key cumulative change in the armed forces. Professionalisation aims to improve the implementation of new tasks.

- Conflict prevention: SSR helps prevent internal and external conflicts. Regarding the former, it is about effective management of tensions and problems, while regarding external conflicts it entails creating regional trust based on an existing professionalised security sector under effective civil control (SSR as a regional confidence-building measure).

- Integration into Western institutions: SSR is an important criterion for joining the EU (in the SAP process) and NATO (in the MAP process). It is known that this criterion was improved based on negative experiences with certain states in previous faster rounds.

\section{Indicators of Democratisation in the Field of National Defence and Comparative Results from Slovenia and Montenegro}

The above text suggests many possible indicators to support further comparative assessments. For the purposes of our paper, we extracted eight indicators that clearly demonstrate the democratisation of national defence in Slovenia and Montenegro. We relied on the qualitative and quantitative comparative methods to extract some similarities and differences in the countries' democratisation. ${ }^{1}$

\section{Socialist legacy as a basis for creating a new defence system - an initial democratic deficit in the defence field}

It is generally agreed that the socialist legacy has hindered SSR in Central, Southern and Eastern Europe. Peterson Ulrich (1999: 183-184) stressed persisting democratic deficits within both civilian and military institutions limiting the full achievement of democratic political control, such as: weakness in budgetary control, lack of expertise on defence issues, a low level of trust in civilian oversight bodies, limited political will to influence defence processes, a poor relationship between the defence ministry and the parliament, a lack of transparency in all democratic institutions, the strong commitment of civilian and military leaders to democracy, deficits in norms of political influence, and the compatibility of military and social values. Croissant - Kuehn (2017: 1) recapitulate the view that reforming post-socialist defence institutions has been challenging due to the ineffectiveness and insufficient preparedness of many new democracies to develop robust institutions to ensure democratic control of the armed forces

1 The limitation of this approach is our narrower focus on SSR in selected countries (we focus predominantly on military/defence institutions in the entire spectrum of security institutions) and our limited number of indicators. Many more indicators could have been a subject or our research, but this would extend the length of this paper well beyond a typical paper in a journal. We should also stress that analysis is done in accordance with the concept of SSR, a newer tool developed at the end of nineties, while some analysed policies are older than that. 
and turn them into effective providers of security. Young (2018: 162-168) also stresses that legacy concepts are actively and passively still evident in European post-communist defence institutions in the form of highly centralised decision-making, the absence of critical thinking, an algorithmic approach to problem-solving, undeveloped defence planning, restrictive interpretation of positive law, the absence of a policy framework, unclear institutional roles/missions, inadequate force management and development, capabilities, a weak defence civilian cadre etc. A large body of literature also considers other broader democratic aberrations occurring in the Western Balkans. Much attention has been placed on the widespread and enduring nexus or symbiosis between politics, the security forces, business and organised crime (United Nations Office on Drugs and Crime 2008: 43; Center for the Study of Democracy 2003). This nexus has been maintained through concealed, informal networks that have extended into the intelligence agencies, military establishments and police services. This has created a high level of impunity for those involved in such criminal activity and explains how organised crime has become entrenched in the Western Balkans with serious effects for the functioning of states, the rule of law, good governance and state weakness (Giatzidis 2007: 331-348; Gyarmati 2003: 55-60). Such a link with organised crime has been called a threat to democracy (National Defense University 1997: 204), the economy and economic development (Hebenton - Thomas 1995: 204) and has also undermined civil society, destabilised the political process and affected the rule of law (Williams 1994: 108-109).

Certain troubling elements of the post-socialist legacy have been revealed in Slovenia and Montenegro, although the situation is gradually improving. For Slovenia, three pressing problems are noted. The first refers to the unclear institutional role of the new security sector (especially the intelligence services) when combined with corruption and ineffective parliamentary control. A series of scandals after independence showed that the government and civil and military intelligence services were involved in the (international) illegal smuggling of arms in order to help the friendly Croatia, Bosniaks and Croats in Bosnia in their fight against the common enemy. Two larger shipments of weapons were uncovered by the Ministry of Internal Affairs (MIA) or the Ministry of Defence $(\mathrm{MoD})$ and the related scandals were used in a mutual political struggle for power. Escalation of this fight led to the "Depala vas" scandal in which military intelligence officers arrested an undercover agent who was working for the police. The police had been investigating a potential coup d'état by the defence minister and his followers. Eventually, the minister of defence lost his position due to having exceeded his authorities. ${ }^{2}$ The second legacy example came in the late 1990s in

2 Also other scandals, reflecting unclear institutional relations and mutual competition, emerged in Slovenia in that time. One of these was scandal VISNOMO, which was based on a systematic release of secret documents implicating both civilian and defence intelligence-security services in illegal activities. 
the form of unrealistic defence planning. The process was based on the typical Eastern European use of military divisions (despite in reality Slovenia having much smaller armed forces) and on the excessive use of lofty goals that were never really achieved in practice. An important external study by US General Garrett concluded that the Slovenian armed forces were "hollow" and its actual capacities are much smaller. Slovenia had to change this in order to join NATO. Another deficit lingering since the country's independence is the seemingly unusual incompatibility between civilian and military values. The country's secession process was largely driven by the idea of demilitarisation (see Grizold 1992: 80; Jelušič 1997: 163) and such an attitude to the armed forces continues among a significant share of the population even after Slovenia established its own armed forces. Today, the armed forces enjoy relatively strong public support (see Garb - Malešič 2016), which is under serious pressure in cases like the local public attitude to the main military training site at Poček. With respect to Montenegro, the post-SFRY socialist legacy was more present in the state union with Serbia (1992-2006) than after it achieved its independence in 2006. During the time of Milošević, there was a considerable lack of transparency in the entire security sector, with secrecy becoming a means for protecting the regime, while significant links between the regime and the criminal underground were detected. War criminals were hidden and drugs and weapons were illicitly trafficked also with the notable assistance of the intelligence and security services. Hadžić (2001: 82) and Djurdjević-Lukić (2007: 160-162) concluded this lack of transparency protracted the security sector reforms and reflected the absence of substantial democratic oversight in the defence sector.

Both cases reveal a chronic lack of military expertise. Slovenia and Montenegro have never established their own military academy and the initial educated personnel were mainly graduates of the Yugoslav military academy in Belgrade. Many professionals with high ranks in YPA were denied a job or promotion in the Slovenian armed forces. Civilian academic defence studies were only able to bridge this lack of military expertise to a certain extent and thus Slovenia developed a unique combination of an internal education system (Staff and Command School) and university defence studies at the University of Ljubljana. However, Montenegro gave a chance to ex-Yugoslav graduates, but still had to largely compensate by educating cadets and military personnel in famous foreign military academies and colleges abroad.

\section{Integration into NATO and effects on the democratisation of defence}

Enlargement has become a key, even a vital, policy of NATO and the EU. It leads to new countries becoming members and is simultaneously a tool for stabilising and democratising the candidate countries. In the national defence 
field, participation in the Partnership for Peace has become a very important and accelerating tool for achieving NATO's standards for prospective members (Mannitz 2013: 21) and for the more abstract sharing of joint values and norms within the transatlantic area. NATO required a "transformation through convergence" (Forster 2010: 17) and a more democratic defence policy and system. Candidate countries were given enormous incentives to implement principles of democratic civil-military relations, adopt norms and guidelines for the oversight of armed forces and to strengthen their accountability (see Ball 2010: 33).

For both Slovenia and Montenegro, it is very clear that their NATO Membership Action Plan literally boosted the democratisation of their national defence and security policy in five dimensions. In the political and economic dimension, NATO expected the candidate countries to resolve conflicts peacefully, respect human rights, create appropriate civilian control over the armed forces etc. In the defence dimension, NATO required a defence-reform process leading to the creation of adequate military capabilities usable for operations in the NATO framework. The security dimension of this process helped in the creation of a reliable secret data protection system, while the legal dimension required adoption of the NATO "acquis". Slovenia became a full NATO member in 2004 and Montenegro in 2017. Their inclusion was ratified in the national parliaments of all NATO member states, meaning they had no political objections regarding the state of their democracy. In Montenegro, the decision to join was adopted by the parliament, while Slovenia also organised a national referendum on joining NATO and the EU in 2003 in which a share of $66.08 \%$ voted in favour of joining NATO.

However, joining NATO has not proven to be a panacea for all of the problems of democratisation in the two countries. We still see democratic aberrations and deficits in the defence and security field. Montenegro is struggling to build up integrity in the defence sector, seen in the imbalance between the practice of free access to information and regulations protecting state secrets (see DiFi Norway 2015: 39). The Law on Data Secrecy (2014) defined secrecy too broadly in terms of national security and defence protection. The procurement of equipment and public tenders seem to be issues in both countries before and after joining NATO. Montenegro has encountered issues of inefficient internal financial and expenditure control and internal audit control (DiFi Norway 2015: 2). The issue of efficient financial management is still being consolidated after NATO accession, as demonstrated by the relatively frequent cases of public procurement procedures being repealed (see Vijesti 2019). In Slovenia, a major political scandal erupted in the process of purchasing Patria armoured modular vehicles in 2008. A procurement contract with Patria worth EUR 278 million (initially for 135 vehicles, but later reduced to 30 ) was the core of a widespread political controversy in 2008 when allegations of corruption and mismanagement emerged, centring on business and government officials in Finland, Austria, 
Croatia and Slovenia (see RAND Europe 2016). The institutional powers of the Defence Intelligence Agency (OVS) also seem to be somewhat unclear as shown by the Veber scandal. A parliamentary committee's supervision of this service in November 2014 disclosed that the Minister of Defence had ordered OVS to conduct an analysis of the effects of the potential privatisation of Telekom Slovenija. Both the parliamentary committee and the prime minister concluded that this act was in gross violation of the authority and constituted political misuse of the intelligence service (RTV 2018; The Slovenia Times 2015).

\section{Change in perceptions from a narrow military to a broader spectrum of security threats}

Once the Cold War and Communism had come to an end, security perceptions across Europe changed significantly. People and states ceased to perceive and prioritise the traditional military threats while several non-military threats were increasingly seen as a national security problem. Many authors (see Pfaltzgraff 1991: 14; Grizold 1999; Prezelj 2000; Hadžić 2004 etc.) stressed the importance of environmental, economic, demographic, criminal, terrorist, health, information and immigration threats, the proliferation of WMD, extremism, ethnic conflicts and so on. This change in security perceptions is relevant for its effect on the reforms of defence and security policies and systems.

Primary national security documents were used to investigate how the threat perception has evolved over time in both countries. The results clearly show the very similar development of threat perceptions from military to non-military. This means that the democratisation of this field in the two countries encountered relatively similar inputs from the security environment. The reduction of inter-state military tensions allowed both countries to further democratise their policies and systems.

Slovenia's national security policy and system were broadly conceived after attaining independence, however the evolution of threat prioritisation is easily detected. The biggest threat to national security in the 1990s was military threat (due to unresolved national, political, military and economic problems among states in former Yugoslavia, potential retaliatory attempts to restore borders and the revival of crises in larger Europe) (Resolucija o izhodiščih zasnove nacionalne varnosti RS 1993). The perception then moved over to 'new' and 'dynamic' non-military threats and risks. After 2000, decision-makers perceived military threats in South-East Europe (SEE) as ones that could only indirectly affect Slovenian national security (Resolucija o strategiji nacionalne varnosti RS 2001). In 2010, a wide spectrum of non-military threats, like climate change, terrorism and public safety threats etc., was recognised by the government (Resolucija o strategiji nacionalne varnosti RS 2010), while hybrid threats were stressed in a more recently adopted document. These threats refer to the multidimensional 
combination of traditional and non-traditional threats performed by state or non-state actors (Resolucija o strategiji nacionalne varnosti RS, 2019). Increasing focus has been given to cyber threats and threats posed by illegal immigration. Montenegro's first National Security Strategy in the new state stressed that conventional military threats could jeopardise national security, but significantly less so than non-military risks and a possible regional crisis (Strategija nacionalne bezbjednosti Crne Gore 2006). A very similar perception is seen in the next document from 2008, although transnational threats were perceived to be dominant and it also mentioned that the country could be threatened by different sorts of IT security risks (Strategija nacionalne bezbjednosti Crne Gore 2008). In the National Defence Strategy, the dangers of military threats are addressed, but the document still prioritised asymmetric threats (Strategija odbrane Crne Gore 2008). The Strategic Defence Review (2010) stressed the possibility of the region being destabilised apart from the above-mentioned threats (Strategijski pregled odbrane 2010). The newest strategic documents adopted since joining NATO in 2017 include cyber and hybrid threats (Strategija nacionalne bezbjednosti, 2018) and illegal migrations, weapons proliferation, energy security etc. (Strategija odbrane Crne Gore 2019).

\section{The creation of new defence institutions (armed forces) and mechanisms for democratic and civil control}

Good governance of the national security sector requires measures and models for the effective, efficient, legitimate and transparent functioning of security institutions (Caparini - Fluri 2000: 8). In this context, it is essential to introduce structural changes and redefine the tasks of the armed forces. It is also vital for modern democracies to create mechanisms for democratic and civilian control of the defence institutions and armed forces (see OECD 2005: 50; Born 2010). Namely, it is about putting the armed forces in democratic order. The first critical measure is to appoint a civilian defence minister instead of a Communist-type military defence minister. He/she is "the key civil controller" of the armed forces (Hadžić 2004: 12, 33) responsible for civilian oversight in many legal areas, like: budget and law proposals, monitoring of financial spending, organisation and formation of the armed forces, as well as promotions, appointments, and the relieving and retiring of soldiers. The number of civilians in defence sector management further adds to democratic control over the armed forces (Tagarev 2008: 110). The next critical measure is to develop effective parliamentary oversight of the armed forces in the form of parliamentary committees for democratic control of defence and the related intelligence service. This is a crucial institution for democratic norms and standards, responsible for supervising and governing military and security agencies, and developing sufficient expertise and review mechanisms in the process of adopting laws, budgets and policies 
(Caparini 2010: 258). However, there is no definitive model for parliamentary oversight of the armed forces and, as Born (2010: 28) states, "democratic control of armed forces is never finished and may always be improved".

Both countries have appointed a civilian defence minister since their independence, whereas defence ministers during the SFRY came from the military. Still, it is true that Slovenia's first civilian defence minister wore a military uniform during the 10-day war for independence with SFRY in 1991. The number of civilians engaged in the defence system of both countries is quite high $(1,134$ in Slovenian and 149 in the Montenegrin MoD in 2018), reflecting a situation in which many civilians are dealing with defence and military matters.

The activities of both defence ministers and their ministries are exposed to public scrutiny and specific control by national assemblies and their specialised committees. The biggest difference between the countries is that there are two main parliamentary committees monitoring the defence sector in Slovenia (Committee for Defence, and Committee for Oversight of Intelligence and Security Services - KNOVS) and a more comprehensive one in Montenegro (Parliamentary Committee for Security and Defence), responsible for overseeing the work of the entire security sector. The later committee was established after the country's independence in 2006 and is based on a comprehensive legal framework completed and improved by adoption of the Law on Parliamentary Oversight within the Area of Security and Defence (Zakon o parlamentarnom nadzoru u oblasti bezbjednosti i odbrane 2010). In Slovenia, defence and intelligence committees existed after independence, but a key improvement in parliamentary control came in 2003 with adoption of the Parliamentary Oversight of Intelligence and Security Services Act (see Zakon o parlamentarnem nadzoru obveščevalnih in varnostnih služb, 2003). On paper, all committees in both countries exercise control using a range of means, including questions by delegates, and parliamentary inquiries, yet both countries have also been criticised for lacking strong and effective control, that is sometimes politicised. For example, it was claimed in Montenegro that the committee generally does not use its full power, that it is very weak and politicised and controls neither budget planning nor spending (Radević - Kalač 2012: 167). It was also claimed that the committee should have been more proactive and used all the mechanisms available for parliamentary control (Muk 2009: 20).

The tasks of the armed forces of both countries have broadened following independence and especially after joining NATO. After Slovenia attained its in independence in 1991, a new Defence and Protection Law was adopted to regulate the defence tasks and structure of the Territorial Defence forces. Under a new Defence Act passed in 1994 (Zakon o obrambi 1994), the defence forces were restructured and renamed the Slovenian Armed Forces (SAF). In terms of parliamentary control, it is very important that the National Assembly adopts or amends the Defence Act with a two-thirds majority of votes instead 
of the normal majority. This makes changes in the defence sector less vulnerable to politicisation because this provision requires that political parties in government and opposition reach an agreement. The Slovenian Government is responsible for implementing and preparing the nation's defence based on decisions of the National Assembly, the Constitution and legislation. The President of the RS is the Commander-in-Chief of the SAF and performs this function according to the Constitution and state laws. Article 37 of the Defence Act defines the armed forces' tasks: providing military education and training for armed combat and other forms of military defence, ensuring the required readiness, conducting military defence, as well as participation in protecting and rescuing in the event of natural and other disasters. Before joining NATO, a very relevant change was introduced to this law. This amendment extended national defence tasks to include involvement and active state participation in international security alliances under international treaties. A similar extension was made to the Constitution in 2003, with Article 3a thereof prescribing that in an international treaty ratified by the National Assembly with a two-thirds majority vote of all deputies Slovenia may transfer the exercise of part of its sovereign rights to international organisations. In 2004, the Defence Law was further amended to allow armed forces to cooperate with the police on wider protection of the state border within the national territory. In 2015, amidst the refugee crisis the law was further extended to authorise the armed forces as part of the protection of the state border to warn or temporarily restrict the movement of persons and control groups and crowds.

The Army of Montenegro was formed in 2007. Articles 130-131 of the Montenegrin Constitution define the Council for Defence and Security as the main body responsible for making decisions in the field of defence and security. The Council comprises the President of Montenegro as president of this body, the Prime Minister and the President of Parliament. This body is responsible for approving the plan for the armed forces, deciding on commanding with those forces, proposing international missions, proposing to declare a state of emergency or war to the parliament, proposing the promotion of military officers/ diplomatic representatives, proposing the use of the armed forces to help the police with border protection etc. (Ustav Crne Gore 2007; Zakon o odbrani Crne Gore 2017; Zakon o vojsci Crne Gore 2017). Slovenia does not possess such a collective decision-making body in the narrower defence field. The tasks of Montenegro's armed forces are also broadly defined in the law, ranging from defending the country's independence, sovereignty and territory, participating in international forces through to other legal tasks like helping in natural disasters (Zakon o vojsci Crne Gore 2017; Zakon o zaštiti i spašavanju 2016). These tasks were broadened within the existing Law on Defence when joining NATO. Two articles on collective defence (Articles 38a and 38b) were added, touching on the role of Parliament and the President in requesting NATO's assistance and 
the possibility that Montenegro's airspace also be protected by NATO (Zakon o odbrani Crne Gore No. 2/17 2017).

\section{Reform of defence budgets and balancing the expenses}

The defence budget or military expenditure is the amount of a country's financial resources it dedicates to its armed forces and related activities. It is an important indicator of both a country's military power and the desire to achieve military capabilities through the proper allocation of resources (Fetterly 2007). Brauner (2015) investigated the relationship between military expenditures and democracy. Democracy appears to have a negative effect on military spending and democracies spend less on the military than autocracies do. The author revealed that an absolute dictatorship spends around $40 \%$ more than a full democracy and that a successful move to democratic rule has a demilitarising impact. In addition, we can observe a typical trend of a growing defence budget in times of the international/internal deterioration of conflicts and a shrinking budget during periods of peace-building and cooperation. SIPRI (2013) gives a more specific assessment for Western and Central Europe: military spending rose in the period 2003-2009 and then decreased.

SSR and good governance of the security sector understand the defence budget as a major element of civilian control of military authorities. Transparency as an essential element of democracy can be assured since the budget and its programmes are decided on by civilian representatives (DCAF 2008). While adopting the military budget, it is critical to determine what is affordable, allocate scarce resources according to priorities both within the defence sector and between the defence and other sectors, identify the needs and crucial objectives of the security sector as a whole, and ensure the efficient and effective use of resources.

The comparative table below (Table 1) shows that Slovenia, as a 3.5-times larger country in population terms and a much richer country in GDP per capita terms, relatively speaking spends much less in terms of defence expenditure as a share of GDP. Interestingly and when viewed generally, the defence budget in relative numbers as a percentage of GDP has been falling since both countries became independent. This may be attributed to the fewer military threats in the region and the democratic redistribution of funds to other needs. The Montenegrin defence budget as a share of GDP was relatively high $(2.26 \%)$ at the time it was reaching independence due to its previous war experience in 1999. Its membership in NATO in 2017 also contributed to the gradual increase in its defence budget. A trend of a rising defence budget is shown in both countries. 
Table 1: Comparative overview of defence expenditure in USD ${ }^{3}$

\begin{tabular}{|c|c|c|c|c|c|c|c|}
\hline Slovenia & $\mathbf{2 0 1 8}$ & $\mathbf{2 0 1 7}$ & $\mathbf{2 0 1 2}$ & $\mathbf{2 0 0 7}$ & $\mathbf{2 0 0 2}$ & $\mathbf{1 9 9 7}$ & $\mathbf{1 9 9 4}$ \\
\hline GDP & $55.0 \mathrm{bn}$ & $48.9 \mathrm{bn}$ & $\mathbf{4 5 . 6} \mathrm{bn}$ & $\mathbf{4 5 . 2 \mathrm { bn }}$ & $\mathbf{2 2 . 0 \mathrm { bn }}$ & $18.2 \mathrm{bn}$ & $14.5 \mathrm{bn}$ \\
\hline GDP Per capita & 26,586 & 23,654 & 22,193 & 22,473 & 11,170 & 10,200 & 6,800 \\
\hline Defence expenditure & $553 \mathrm{~m} *$ & $477 \mathrm{~m} *$ & $509 \mathrm{~m}$ & $741 \mathrm{~m}$ & $275 \mathrm{~m}$ & $329 \mathrm{~m}$ & $290 \mathrm{~m}$ \\
\hline $\begin{array}{c}\text { Defence expenditure } \\
\text { in \% of GDP }\end{array}$ & 0.97 & 0.97 & 1.12 & 1.64 & 1.2 & 1.8 & 2.1 \\
\hline Population & $2,102,126$ & $1,972,126$ & $1,996,617$ & $2,009,245$ & $1,964,000$ & $2,017,000$ & $2,007,000$ \\
\hline Montenegro & $\mathbf{2 0 1 8}$ & $\mathbf{2 0 1 7}$ & $\mathbf{2 0 1 2}$ & $\mathbf{2 0 0 7}$ & & & \\
\hline GDP & $5.39 \mathrm{bn}$ & $4.78 \mathrm{bn}$ & $4.28 \mathrm{bn}$ & $2.6 \mathrm{bn}$ & & & \\
\hline GDP Per capita & 8,644 & 7,678 & 6,882 & 3,801 & & & \\
\hline Defence expenditure & $85 \mathrm{~m} *$ & $66 \mathrm{~m} *$ & $52 \mathrm{~m} * * *$ & $59 \mathrm{~m}$ & & & \\
\hline $\begin{array}{c}\text { Defence expenditure } \\
\text { in \% of GDP }\end{array}$ & 1.47 & 1.57 & 1.20 & 2.26 & & & \\
\hline Population & 614,249 & 642,550 & 657,394 & 684,736 & & & \\
\hline
\end{tabular}

Source: IISS, Military Balance 2019, 2018, 2013, 2008, 2004, 2002, 1999, 1997, 1995

The National Assembly of the Republic of Slovenia exercises control over the security sector and the SAF particularly through its Committee on Budget and Finance and through the allocation of defence funds via the defence budget (Jelušič 2007: 2-6). On the other hand, the defence budget is an essential vehicle for providing the basis for constant modernisation, equipping and operational actions (Resolucija o splošnem dolgoročnem programu razvoja in opremljanja Slovenske vojske do leta 20252010). The Slovenian government's long-term plan for defence expenditure is $2 \%$ of GDP, but the economic situation means the plan will not be realised before 2025. According to Furlan - Barjaktarjević (2019: 101), the lowest level of defence expenditure was in 2015 (0.93\% of GDP), with the main reason for this rapid decline being the financial and economic crisis. The defence sector has lost one-third of its budget, going from USD 750 million in 2007 to a projected USD 532 million in 2018.

Montenegro had the biggest budget (2.26\% of GDP) in 2007 right after the Defence Ministry and the Army of Montenegro were established and institutionalised. This share of the budget also had NATO accession in mind. Due to the Plan of Investment in the Defence Sector 2018-2024 and the process of defence reforms, it is also expected that the defence budget will increase in the following years to $2 \%$ of GDP (including military pensions) (see Izvještaj o radu i stanju u upravnim oblastima iz nadleznosti Ministarstva odbrane za 2017. godinu 2018).

3 Data for Montenegro are shown only since its independence.

Legend: * NATO definition; ** includes military pensions; *** excludes military pensions 


\section{Professionalisation of the armed forces: from a conscript to a professional force}

The transformation of military structures raises questions regarding the size and personnel composition of the armed forces. Janowitz (1971) argued early on that countries will follow the general spirit of the new trend towards smaller, fully professional, and self-contained military forces. Large conscript-based force structures and land-based territorial defence forces are no longer a priority after the Cold War. The number of military recruits has started to exceed demand, questioning the need for a conscript army in many countries (Haltiner - Klein 2005: 9-13). The carrying out of military tasks with fewer soldiers (Hosek 2003) or, generally, reducing the armed forces is also a fundamental element of defence transformation (Haltiner - Klein 2005; Hänggi 2004; Law 2004). At the same time, defence transformation is closely linked to professionalisation, which enables the armed forces to perform their newly defined tasks and better meet future challenges and requirements (Edmunds 2004; Hadžić 2004). One can say that the image of highly trained and specialised professional personnel has replaced the former ideal of a patriotic warrior.

A comparison of the two countries reveals a general decrease in the total number of personnel. Conscript armed forces have been called into the question and both countries have shifted towards a fully professional force (Montenegro did so upon independence while Slovenia changed its system in 2003). We should also note that some reductions might also be simply due to the lack of recruitment or bureaucratic measures to remove the 'hollow forces'.

Table 2: Personnel in the armed forces

\begin{tabular}{|c|c|c|c|c|c|c|c|}
\hline Slovenia & 2018 & 2017 & 2012 & 2007 & 2002 & 1997 & 1994 \\
\hline Active soldiers & 7,250 & 7,250 & 7,600 & 5,973 & $\begin{array}{c}9,000 \\
\text { (including } \\
\text { conscripts) }\end{array}$ & $\begin{array}{c}9,550 \\
\text { (including } \\
\text { conscripts) }\end{array}$ & $\begin{array}{c}8,400 \\
\text { (including } \\
\text { conscripts) }\end{array}$ \\
\hline CONSCRIPTS & & & & & $\begin{array}{l}4,000- \\
5,000\end{array}$ & 5,500 & 5,500 \\
\hline Montenegro & 2018 & 2017 & 2012 & 2007 & & & \\
\hline Active soldiers & $\begin{array}{c}1,950 \\
\text { (Army 875, } \\
\text { Navy 350, } \\
\text { Air Force } \\
225, \\
\text { Other } \\
500 \text { ) }\end{array}$ & $\begin{array}{c}1,950 \\
\text { (Army 875, } \\
\text { Navy 350, } \\
\text { Air Force } \\
225, \\
\text { Other } \\
500 \text { ) }\end{array}$ & $\begin{array}{c}2,080 \\
\text { (Army } \\
1,500, \\
\text { Navy 350, } \\
\text { Air Force } \\
230 \text { ) }\end{array}$ & $\begin{array}{c}5,800 \\
\text { (Army } \\
2,500, \\
\text { Navy } \\
3,300)\end{array}$ & & & \\
\hline
\end{tabular}

Source: IISS, Military Balance 2019, 2018, 2013, 2008, 2004, 2002, 1999, 1997, 1995 
The SAF's strategic reform goal is to form a modern, efficient, rational, small and well-equipped army that provides for national defence and enables cooperation in NATO's collective defence and peace-support operations (Prezelj 2008). In the context of professionalisation of the force, a significant reduction was made from 72,000 in 1997 to around 38,500 members in 2002 (active + reserve members). The transformation to a professional army with contractual reserves enabled a further size reduction to 7,250 active and 1,500 reserve members in 2018.

Montenegro had 5,800 active military personnel in 2007 in a force inherited from the State Union of Serbia and Montenegro. All personnel were given the opportunity under the Law on the Armed Forces of Yugoslavia to choose in which union member state they wished to continue their future military service. This was a very democratic consensual reform point in the process of the union's peaceful dissolution. With a decision of the president of state in August 2006, the existing conscription was abolished (see Tahirović - Injac 2016: 46). Since being established, the Army of Montenegro has been a professional military force reduced from 2,080 personnel in 2012 to 1,950 in 2017. The new Strategic Defence Review and New Formation of the Army of Montenegro contain plans to continue decreasing personnel numbers to 1,800 .

\section{Changes to the personnel policy: gender composition of the armed forces as an example of democratic representativeness}

Gender mainstreaming and growing awareness of the importance of women's participation in peace and security management has become an inevitable element of defence policy and related personnel policy. The main idea of the feminist approach is that $50 \%$ of the world's population is female and, without females, genuine and sustainable peace cannot be achieved. Accordingly, gender integration into the armed forces is vital. There are three gender perspectives on the security sector: 1) respect of universal human rights; 2) men and women are equal and must be involved in decision-making processes; and 3) gender mainstreaming could improve operational effectiveness (Arostegui 2015: 8). The representation of women in key armed forces positions seems not to pose a challenge to the military profession (Schnabel - Farr 2012: 79). A positive-action system is increasing women's representation in the armed forces where the average in some countries is $10 \%$. This is an estimated standard in OSCE countries as determined by the Women in the Armed Forces in the OSCE Region report (Atkins 2018: 3). The improved role played by women in the armed forces is also the result of endeavours of the UN, its international legal framework and resolutions arguing for the promotion of gender equality in peace and security, ensuring the participation of women in decision-making, and integrating gender perspectives in all processes (Arostegui 2015; also see 
Groothedde 2013: 13). Excluding women from the armed forces and holding them back from certain positions in the armed forces can be considered to amount to gender inequality.

The comparative assessment of the two countries shows they both have increasingly enabled women's participation in the armed forces and thereby added to the force's stronger democratic representativeness. In Slovenia, it is obvious that each major reform process, especially the creation of the country's own armed force in 1991 and abolishing the conscript force in 2003, were important legal steps giving women equal joining, recruiting and career-making opportunities in the force (Brožič - Pešec 2017: 125). The current Defence Act includes the principle of equal opportunity for men and women in employment (Article 92). Female members are integrated into units under the command of the Chief of General Staff, work and train together with men, and are subject to the same chain of command, standards and discipline. According to the Ministry of Defence (September 2019), women constitute $16.5 \%$ of the military structure. This share is one of the highest among NATO member states. At the end of the 1990s, the share of women in the SAF was 13\%, ranking the Slovenian army among the most feminised armed forces in the world. Also extremely relevant is the appointment of Major General Alenka Ermenc as the Slovenian army's Chief of Staff in 2018. According to the MoD, in no other NATO member state does a woman currently hold this position (RTV 2019). Female officers also have worked as information and personnel officers in international military operations and in 2011 one of these officers reached the highest female rank in the SAF: brigade general (Vuga Beršnak - Jelušič 2015). In 2017, Major Nina Raduha was the first female commanding officer of a contingent in UNIFIL (United Nations Interim Force in Lebanon) (Obramba 2017). The director of the national police in Slovenia is also female.

Montenegro's security sector features more women than in other sectors. According to data from June 2019, the share of women in the MoD is $49.26 \%$, in the Agency for National Security $38.5 \%$ and in the Ministry of the Interior $58.1 \%$. The vast majority of women in the MoD are administrative civil servants $(63.23 \%)$ and, incomparably less, non-commissioned officers (16.67\%) and officers (0.23\%) (Karović-Brčvak 2019: 32-35). Women accounted for 10.69\% (193 women) of the Army of Montenegro in 2019. These figures are a significant rise since 2013 when the share was $8.97 \%$. Female army members are employed more in civilian positions, such as in the medical service, logistics or military police (SEESAC/UNDP 2014: 14). Currently, nine female cadets are enrolled in military academies abroad (Karović-Brčvak 2019: 34). It is very interesting that the first cadet from Montenegro, who graduated from West Point, the most prestigious military academy in the USA, in June 2019 is a young woman (Vijesti 2019). Another story concerns Kristina Bačić, the country's first woman pilot in the armed forces, who graduated from an air force academy in Greece. Statistics 
also show that nine women from the Army of Montenegro have participated in international missions. A female officer was appointed Gender Advisor to the Commander of NATO Allied Command Operations in July 2018 (Karović-Brčvak 2019: 34).

\section{Transition from security consumer to security provider: participation in international peace-keeping and peace-building operations}

The proliferation of violent and complex conflicts and crises after the Cold War added to the need for international peace-keeping and peace-building operations. Countries' participation in international multilateral operations is appreciated and understood as demonstrating accountability and willingness to share responsibility for international peace and stability. Schnabel and Farr (2012: 20) argue that the preparedness of security providers to meet a threat and assure peace and stability abroad is critical, while Lunn (2002: 93) understands this as proof of the improved political sensitivity to local conditions and consequences. Most multilateral military operations are led by UN and NATO frameworks. Especially the former has developed extensive standards of interoperability of military equipment, operating procedures and command and control mechanisms (Forster 2010: 15). Many SEE states became effective security providers through multilateral military operations stimulated by NATO and to some extent the EU, and their enlargement processes.

Comparing the two countries shows they both act as responsible security providers abroad. Kosovo is a major focus of the Slovenian contribution, while Afghanistan is a focus of the Montenegrin contribution. Their initial participation rose significantly in 2012: Slovenia to 431 and Montenegro to 43 soldiers.

The ability to take part in international military operations is central to Slovenia's defence strategy. The SAF first deployed members in 1997 to the OSCE multinational peacekeeping force ALBA in Albania and to UNFICYP in Cyprus. In 2007, with all-volunteer armed forces the SAF deployed a battalion-sized unit to Kosovo, and commanded the other Alliance troops. Today, the country contributes to EU, NATO, UN and OSCE operations, exercises with other member states, and assists in missions in SEE (IISS 2016). Due to security sensitivity after the Yugoslav wars, the SAF were not seriously deployed in the Western Balkans before 2002.

The Army of Montenegro participates in several international military missions - Resolute Support (Afghanistan), EU NAVFOR Atalanta (Somalia), EUTM (Mali), UN MINURSO (Western Sahara) and UNMIL (Liberia) (Ministarstvo odbrane Crne Gore 2019). Since 2018, Montenegro has deployed military staff to two more NATO missions: KFOR (Kosovo) and the multinational Enhanced 
Table 3: Participation in foreign military operations

\begin{tabular}{|c|c|c|c|c|c|c|c|}
\hline Slovenia & 2018 & 2017 & 2012 & 2007 & 2002 & 1997 & 1994 \\
\hline $\begin{array}{c}\text { AFGHANISTAN: NATO } \\
\text { (Operation Resolute } \\
\text { Support) }\end{array}$ & 8 & 7 & 77 (ISAF) & 42 (ISAF) & & & \\
\hline $\begin{array}{c}\text { BiH: EU - EUFOR } \\
\text { (Operation Althea) }\end{array}$ & 14 & 14 & 14 & 58 & $\begin{array}{c}78 \\
(\text { SFOR II) } \\
\end{array}$ & & \\
\hline $\begin{array}{l}\text { IRAQ (Operation } \\
\text { Inherent Resolve) }\end{array}$ & 6 & 6 & & $\begin{array}{c}4 \\
(\mathrm{NTM}-\mathrm{I}) \\
\end{array}$ & & & \\
\hline $\begin{array}{l}\text { LATVIA: NATO (Enhanced } \\
\text { Forward Presence) }\end{array}$ & 50 & 50 & & & & & \\
\hline LEBANON: UN - UNIFIL & 18 & 15 & 14 & & & & \\
\hline MALI: EU - EUTM & 4 & 4 & & & & & \\
\hline $\begin{array}{l}\text { MIDDLE EAST: UN - } \\
\text { UNTSO }\end{array}$ & 3 & 3 & 3 & 2 & 2 & & \\
\hline SERBIA: NATO - KFOR & 241 & 252 & 323 & $\begin{array}{c}92 \\
\text { (Joint } \\
\text { Enterprise) }\end{array}$ & 6 & & \\
\hline UKRAINE: OSCE & 1 & 2 & & & & & \\
\hline ALBANIA: OSCE - ALBA & & & & & & 25 & \\
\hline CYPRUS: UNFICYP & & & & & & 27 & \\
\hline SUM & 345 & 353 & 431 & 198 & 86 & 52 & \\
\hline
\end{tabular}

\begin{tabular}{|c|c|c|c|c|}
\hline Montenegro & 2018 & 2017 & 2012 & 2007 \\
\hline $\begin{array}{c}\text { AFGHANISTAN: NATO } \\
\text { (Operation Resolute } \\
\text { Support) }\end{array}$ & 20 & 18 & 41 (ISAF) & \\
\hline MALI: EU - EUTM & 1 & 1 & & \\
\hline UKRAINE: OSCE & 3 & 2 & & \\
\hline $\begin{array}{c}\text { WESTERN SAHARA: UN - } \\
\text { MINURSO }\end{array}$ & 2 & 2 & & \\
\hline ALBANIA: OSCE & & 1 & & \\
\hline SERBIA: OSCE & & 1 & & \\
\hline LIBERIA: UNMIL & & & 2 & 2 \\
\hline $\begin{array}{l}\text { Foreign forces - Ireland } \\
\text { OSCE }\end{array}$ & & & & 1 \\
\hline SUM & 26 & 25 & 43 & 3 \\
\hline
\end{tabular}

Source: IISS, Military Balance 2019, 2018, 2013, 2008, 2004, 2002, 1999, 1997, 1995

Forward Presence (eFP) Battalion Battle Groups (Latvia) ${ }^{4}$. Before 2018, Montenegro did not participate in any regional missions but at the end of that year

4 The data for Montenegrin participation in the mission EU NAVFOR Atalanta, KFOR and eFPare not shown in table. 
it decided to deploy two officers in KFOR, a mission with a regional character (Kosovo). However, this decision has been protracted due to political sensitivity and the close bilateral relations with Serbia.

\section{Conclusion}

This paper shows that the democratisation of the defence and security sector lies at the heart of the democratisation of any state in the region. We are able to confirm the claim that serious and significant progress in democratising defence and security in Slovenia and Montenegro came after dealing with the post-socialist legacy, the reduction of military threats and joining NATO. We can observe that both countries have sought to strike a balance between the effectiveness of the defence and security sector and the effectiveness of democratic and civilian control.

In terms of progress with democratisation, we found that the socialist legacy has hindered the democratisation and related reforms of the defence and security sectors in both countries. We noted problems like the unclear institutional role, lack of transparency, overuse of secrecy, elements of corruption, ineffective parliamentary control and the chronic lack of military expertise. However, the democratisation of defence and security benefited immensely from the very structured process of joining NATO. Ratification of their membership by all member states' parliaments means no political objection was raised against the state of democracy in relation to their national defence and security systems. Both countries have shown clear progress in adopting joint values and norms, the ability to resolve conflicts peacefully, respect for human rights, adopting the NATO acquis, organising appropriate civil control over the security sector, functional armed forces that can contribute to allied foreign operations, relatively reliable secrecy-protection systems etc. Threat perceptions in both countries have moved from military to non-military, creating space for many democratic reforms in the security sector. Still, both countries have started to perceive hybrid threats (military and non-military threat combinations) in light of the deteriorating relations between Russia and the West. Slovenia and Montenegro established new armed forces after achieving their independence under a civilian defence minister, with a relatively large number of civilian staff responsible for defence issues in the $\mathrm{MoD}$, new parliamentary committees to control the armed forces and the entire security sector. Moreover, the tasks of the armed forces are defined sufficiently narrowly or broadly in the two countries. A major change was seen in both countries just prior to joining NATO in terms of adding the defence of allied territory to their existing constitutions and legislation. The defence budgets in the two countries reflect a democratic redistribution of resources from military to other sectors (in the form of lower defence budgets), yet both countries plan to raise their military funding in light 
of the growing uncertainty in the international security environment. The trend of reducing the total number of active soldiers and shifting from a conscript to a fully professional force (in 2003 by Slovenia, in 2006 by Montenegro) is evident in both countries. Democratic representativeness is reflected in both countries by the relatively large share of women in the armed forces $(16.5 \%$ in Slovenia, 10.69\% in Montenegro), with women training and graduating alongside men and taking up important command positions. The deployment of the armed forces to foreign operations shows both countries have developed from being a security consumer to a security provider. The two countries have also considerably increased their participation in such operations.

In terms of differences between the countries, the biggest one is the timing of the democratic changes. Slovenia achieved independence much sooner than Montenegro and thus most changes came sooner. This enabled Slovenia to play a special mentoring role in the area of defence reforms in Montenegro. We should also mention that Montenegro suffered tougher post-socialist issues during the time under Slobodan Milošević in the joint state union with Serbia, while Slovenia was already free. Perhaps the most obvious differences are structural, such as the existence of only one comprehensive parliamentary monitoring committee in Montenegro instead of two in Slovenia and the existence of the Council for Defence and Security as a collective decision-making body in Montenegro. There is no such body in Slovenia (at least in peace time). It is evident that Montenegro as a smaller and economically less developed country than Slovenia dedicates significantly more funding to defence as a share of GDP. Slovenia probably has one of the most feminised armed forces in the world with women at the top of the armed forces and also at the top of the country's police force. While Montenegro still does not send many soldiers to international operations in the SEE region, this will improve in the future as happened in the Slovenian case.

The SSR concept suggests that no society can ever achieve perfection when it comes to democratisation. Obviously, the transformation of defence institutions in both countries is continuing and sometimes lags behind the progress already achieved in other democratic institutions. The most serious challenges perhaps relate to the effectiveness of the parliamentary control over the armed forces and intelligence services in both countries. The key lesson here is that the two countries have done a lot, but more still needs to be done to improve the nexus of democratic and security culture for all stakeholders, such as parliamentarians, ministers, directors of defence and security agencies, employees, the media etc.

Our results should also be considered from the perspective of the division between external and internal factors that has added to the quality of democracy in the two countries. The factors identified above are both internal and external in origin. Yet it seems that the biggest drivers of democratic change in these countries have been external, such as the collapse of Communism in other Eu- 
ropean countries, the associated end of the East-West conflict and reduction of military threats in Europe's security environment. This external 'confusion' was bridged by the NATO enlargement policy that appears to be the strongest external factor contributing to the democratic changes in both countries. These external factors enabled internal factors to play an important role. The shift in threat perceptions paved the way for several internal structural reforms, such as civilian defence ministers, a large number of civilians in defence establishments, reducing defence budgets and the total number of soldiers (accompanied by a change from a conscript to a professional armed force) etc. The greater democratic representativeness in terms of the percentage of women in the armed forces seems to be equally driven by the external and internal trends of women's growing rights across Europe.

Another question is the significance of the above factors from the perspective of the resilience of democracy in the two states. We see two main threats to democracy in the field of defence and security in both countries. The first threat stems from the major deterioration of the security situation in wider Europe (e.g. Russia-West) or in the Western Balkans. Both democracies could swiftly encounter the need to change their threat perception and reverse the above-mentioned trends (e.g. an increase in defence and security budgets, an increase in soldiers etc.). This scenario would lead to increased security powers of the whole security apparatus that could seriously test and shake the resilience of both democracies. Another related threat coming from within each country is the major weakness of the democratic political system in the shape of a democratically elected authoritarian state leader who seeks to gradually start breaking up the democratic elements of each state or at least reduce their efficiency. Let us simply recall the acts of Hitler and Mussolini who integrated German and Italian societies in relation to perceived internal and external threats and at the expense of democracy in both states. Modern democracies remain weak in this scenario.

\section{References}

Agency for Public Management and eGovernment of Norway - Difi (2015): Montenegro: Building Integrity in the Defense Sector: available at: https://cids.no/wpcontent/ uploads/pdf/ difi/difi_report_2015_10_montenegro_building_integrity_in_the_defence_sector.pdf (12 May 2020).

Arostegui, Julie L. (2015): Gender and the Security Sector: Towards a More Secure Future. Connections: The Quarterly Journal 14 (3): 7-30.

Atkins, Susan (2018): Women in the Armed Forces in the OSCE Region, OSCE, Office for Democratic Institutions and Human Rights, Baseline Study Report. 
Ball, Nicole (2010): The Evolution of the Security Sector Reform Agenda, in Sedra, Mark, ed., The Future of Security Sector Reform, 29-44, The Centre for International Governance Innovation (CIGI).

Bearne, Susanna - Oliker, Olga - O'Brien, Kevin A. - Rathmell, Andrew (2005): National Security Decision-Making Structures and Security Sector Reform, Rand Corporation.

Born, Hans (2010): Parliamentary Oversight of the Armed Forces: Introduction, in Born, Hans Caparini, Marina - Fluri, Philipp, eds., Security Sector Reform and Democracy in Transitional Societies, 28, DCAF.

Brauner, Jennifer (2015): Military spending and democracy. Defence and Peace Economics 26 (4): 409-423.

Brožič, Liliana - Pešec, Mojca (2017): Ženske v oboroženih silah - primer Slovenske vojske. Teorija in praksa 54 (1): 112-128.

Caparini, Marina - Fluri, Philipp (2000): Introduction: The Relevance of Democratic Control and Reform of the Security Sector, in Born, Hans - Caparini, Marina - Fluri, Philipp, eds., Security Sector Reform and Democracy in Transitional Societies, 8-11, DCAF.

Caparini, Marina (2010): Civil Society and the Future of Security Sector Reform, in Sedra, Mark, ed., The Future of Security Sector Reform, 244-262, The Centre for International Governance Innovation (CIGI).

Center for the Study of Democracy (2003): Corruption, Contraband and Organized Crime in Southeast Europe. Sofia: available at http://seldi.net/fileadmin/public/PDF/Publications/ CorruptionContraband.pdf (June 132017).

Croissant, Aurel - Kuehn, David (2017): Introduction, in Croissant, Aurel - Kuehn, David, eds., Reforming Civil-Military Relations in New Democracies: Democratic Control and Military Effectiveness in Comparative Perspectives, Springer International Publishing.

DCAF (2008): Democratic Control of Armed Forces; DCAF Backgrounder: available at https:// www.files.ethz.ch/isn/55845/17_bg_dem_control_armed_forces.pdf (2 August 2019).

Djurdjević-Lukić, Svetlana (2007): Defence Reform in Serbia and Montenegro: Hampering Exceptionalism, in Ebnöther, Anja H. -Fluri, Philipp H. -Jureković, Predrag, eds., Security Sector Governance in the Western Balkans, 161-183, DCAF.

Edmunds, Thimoty (2004): Security Sector Reform: Concepts and Implementation, in Fluri, Philip - Hadžić, Miroslav, eds., Sourcebook on Security Sector Reform, 45-60, DCAF.

Fetterly, R. E (2007): Problems Inherent in the International Comparison of Defence Expenditures. Canadian Military Journal 1 (8): 89-92.

Fluri, Philip (2004): Introduction, in Fluri, Philip - Hadžić, Miroslav, eds., Sourcebook on Security Sector Reform, 7-8, Geneva Centre for the Democratic Control of Armed Forces (DCAF).

Forster, Anthony (2010): West Looking East: Civil-Military Relations Policy Transfer in Born, Hans Caparini, Marina - Fluri, Philipp, eds., Security Sector Reform and Democracy in Transitional Societies, 15-19, DCAF.

Furlan, Branimir - Barjaktarević, Zoran (2019): NATO and Slovenia 15 Years on: How Accurate were Projections About Defence Expenditure. Contemporary Military Challenges 21 (3): 95-108. 
Garb, Maja - Malešič, Marjan (2016): The Causes of Trust and Distrust in the Military. Defense \& Security Analysis 32 (1): 64-78.

Giatzidis, Emil (2007): The Challenge of Organized Crime in the Balkans and the Political and Economic Implications. Journal of Communist Studies and Transition Politics (23) 3: 327-351. Grizold, Anton (1992): Oblikovanje slovenske nacionalne varnosti, in Grizold, Anton, ed., Razpotja nacionalne varnosti, 59-93, Ljubljana, FDV.

Grizold, Anton (1999): Obrambni sistem Republike Slovenije, Visoka policijsko-varnostna šola. Groothedde, Stephanie (2013): Gender Makes Sense: A Way to Improve Your Mission, Civil-Military Cooperation Centre of Excellence (CCOE).

Gyarmati, Istvan (2003): Security Sector Reform as a Contribution to Crime Prevention in SEE. Connections 2 (2): 55-60.

Hadžić, Miroslav (2001): Manjak pretpostavki za demokratsku kontrolu Vojske Jugoslavije, in Hadžić, Miroslav, ed., Demokratska kontrola vojske I policije u SR Jugoslaviji, 63-98, Beogradski centar za bezbednosnu politiku.

Hadžić, Miroslav (2004): The Concept of Security Sector Reform, in Fluri, Philip - Hadžić, Miroslav, eds., Sourcebook on Security Sector Reform, 11-44, DCAF.

Haltiner, Karl - Klein, Paul (2005): The European Post-Cold War Military Reforms and their Impact on Civil-Military Relations, in Kernič, Franz - Klein, Paul - Haltiner Karl, eds., The European Armed Forces in Transition: A Comparative Analysis, Peter Lang GmbH, Internationaler Verlag der Wissenschaften.

Hänggi, Heiner (2003): Making Sense of Security Sector Governance, in Hänggi, Heiner - Winkler, Theodor W., eds., Challenges of Security Sector Governance, 3-24, DCAF \& LIT Verlag.

Hänggi, Heiner (2004): Conceptualising Security Sector Reform and Reconstruction, in Bryden, Alan - Hänggi, Heiner, ed., Reform and Reconstruction of the Security Sector, 3-18, DCAF \& LIT Verlag.

Hebenton, Bill, and Terry Thomas (1995): Policing Europe: Cooperation, Conflict and Control. London: St. Martin's Press.

Hosek, James R. (2003): The Soldier of the 21st Century, in Johnson, Stuart E. - Libicki, Martin C. - Treverton, Gregory F., eds., New Challenges New Tools for Defense Decision making, 181-209, RAND.

IISS, The International Institute for Strategic Studies (1995): The Military Balance, 1995, IISS.

IISS, The International Institute for Strategic Studies (1997): The Military Balance, 1997, IISS.

IISS, The International Institute for Strategic Studies (1999): The Military Balance, 1999, IISS.

IISS, The International Institute for Strategic Studies (2002): The Military Balance, 2002, IISS.

IISS, The International Institute for Strategic Studies (2004): The Military Balance, 2004, IISS.

IISS, The International Institute for Strategic Studies (2008): The Military Balance, 2008, IISS.

IISS, The International Institute for Strategic Studies (2013): The Military Balance, 2013, IISS.

IISS, The International Institute for Strategic Studies (2016): The Military Balance, 2016, IISS.

IISS, The International Institute for Strategic Studies (2018): The Military Balance, 2018, IISS. 
IISS, The International Institute for Strategic Studies (2019): The Military Balance, 2019, IISS. Janowitz, Morris (1971): The Professional Soldier: A Social and Political Portrait, Free Press. Jelušič, Ljubica (1997): Legitimnost sodobnega vojaštva, Fakulteta za družbene vede. Jelušič, Ljubica (2007): The Defence System of the Republic of Slovenia - Normative Contruction and Civil-Military Relations. Peace Research Institute Frankfurt, Research Paper No. I/12-2007: available at https://www.hsfk.de/fileadmin/HSFK/hsfk_downloads/ Slovenia-12. pdf (2 October 2019).

Karović-Brčvak, Dženita (2019): Zastupljenost žena u sektoru bezbjednosti: ključna dostignuća i preporuke 2013-2019, Centar za demokratiju i ljudska prava - CEDEM.

Kuhlman, Jurgen - Callaghan, Jean (2000): Military and Society in 21st Century Europe. A Comparative Analysis, Lit Verlag.

Law, David (2004): Security Sector Reform in the Euro-Atlantic Region: Unfinished Business, in Bryden, Alan - Hänggi, Heiner, ed., Reform and Reconstruction of the Security Sector, 21-43, DCAF \& LIT Verlag.

Lunn, Simon (2002): The Democratic Control of Armed Forces in Principle and Practice. Partnership for Peace Consortium of Defense Academies and Security Studies Institutes. Connections 1(4): 83-102.

Mannitz Sabine (2013): The "Democratic Soldier": Comparing Concepts and Practices in Europe, Chapter: Civil-Military relations in European Democracies, Ubiquity Press Ltd., DCAF, SSR Paper 9.

Ministarstvo odbrane Crne Gore (2018): Izvještaj o radu i stanju u upravnim oblastima iz nadležnosti Ministarstva odbrane za 2017. Godinu, Podgorica, Mart 2018.

Ministarstvo odbrane Crne Gore (2019): Mirovne misije: available at http://www.mod. gov.me/ rubrike/Mirovne_misije (14 October 2019).

Muk, Stevo: (2009). Parlamentarna kontrola sektora odbrane I bezbjednosti u Crnoj Gori, Institut Alternativa: available at http://media.institutalternativa.org/2011/01/institut-alternativa-parlamentarna-kontrola-sektora-bezbjednosti-i-odbrane-u-crnoj-gori-kako-dalje.pdf (11 October 2019).

National Defense University (1997): Strategic Assessment 1997: Flashpoints and Force Structure. Washington: National Defense University, Institute for National Strategic Studies. Obramba (2017): 'Prva poveljnica v silah UNIFIL je Slovenka': available at http://www.obramba.com/ novice/prva-poveljnica-v-silah-unifil-je-slovenka/ (3 October 2019).

OECD (2005): Security System Reform and Governance. DAC Guidelines and Reference Series: available at shorturl.at/dkBDE (9 November 2019).

Peterson Ulrich, Marybeth (1999): Democratizing Communist Militaries: The Cases of the Czech and Russian Armed Forces, University of Michigan Press.

Pfaltzgraff, Robert L. (1991): The Emerging Global Security Environment. Annals of American Academy of Political and Social Science 517 (14): 10-24.

Prezelj, Iztok (2000): Varnost sodobne družbe kot večdimenzionalni pojav: oblikovanje metodološkega modela proučevanja ogrožanja varnosti, Fakulteta za družbene vede. 
Prezelj, Iztok (2008): Iskustva Republike Slovenije iz procesa uključivanja u NATO, in Tatalović, Siniša, ed., Hrvatska i europsko sigurnosno okruženje, 43-58, Centar za sigurnosne studije, Sveučilište u Zagrebu, Zagreb.

Radević, Rajko - Kalač, Emir (2012): Montenegro (country case studies), in Kloper, Franziska Cantwell, Douglas, eds., Almanac on Security Sector Oversight in Western Balkans, 159- 177, Norwegian Royal Ministry of Foreign Affairs, BCSP, DCAF.

RAND Europe (2016): Central and Eastern European countries: measures to enhance balanced defence industry in Europe and to address barriers to defence cooperation across Europe: available at https://eda.europa.eu/docs/default-source/documents/rr-1459-eda-central-and-eastern-europe-report---technical-annex---final.pdf (9 May 2020).

Resolucija o izhodiscih zasnove nacionalne varnosti RS (1993), Uradni list, no. 71, 30. 12.

Resolucija o strategiji nacionalne varnosti RS (2001), Uradni list, no. 56, 6. 7.

Resolucija o strategiji nacionalne varnosti RS (2010), Uradni list, no. 27, 2. 4.

Resolucija o strategiji nacionalne varnosti RS, (2019): Uradni list RS, no.92/07, 26 September 2019.

RTV Slovenija (2018): 'Alenka Ermenc, Edina ženska na čelu vojsk članic Nata. Imenovanje odmeva v tujini': available at shorturl.at/ozSXO (3 October 2019).

Schnabel, Albrecht - Farr, Vanessa, eds. (2012): Back to the Roots: Security Sector Reform and Development. DCAF.

RTV Slovenija (2018): Janko Veber odhaja iz SD-ja. Levanič: Očitno je prevladala želja po lastni stranki: available at https://www.rtvslo.si/slovenija/janko-veber-odhaja-iz-sd-ja-levanic-ocitno-je-prevladala-zelja-po-lastni-stranki/442438 (10 May 2020).

Schroeder, Ursula C. (2010): Measuring Security Sector Governance, DCAF, Occasional Paper, no. 20.

SEESAC/UNDP (2014): Položaj žena u oružanim snagama zemalja Zapadnog Balkana: available at http://www.seesac.org/f/docs/Gender-and-Security/The-Position-of-Women-in-the-Armed-Forces-in-the-Western-Balkans-MNE.pdf (12 October 2019).

SIPRI, Stockholm International Peace Research Institute (2013): SIPRI Yearbook: 3. Military expenditure: available at https://www.sipri.org/yearbook/2013/03 (1 August 2019).

Skupština Crne Gore (2007): Ustav Crne Gore, Službeni list Crne Gore No.1/2007, Podgorica 2007.

Skupština Crne Gore (2010): Zakon o parlamentarnom nadzoru u oblasti bezbjednosti I odbrane, Sluzbeni list Crne Gore, No.080/10, December 2010.

Strategija nacionalne bezbjednosti (2018): Vlada Crne Gore, Podgorica, jun 2018.

Strategija nacionalne bezbjednosti Crne Gore (2006): Vlada Crne Gore, Podgorica, Jun 2006.

Strategija nacionalne bezbjednosti Crne Gore (2008): Vlada Crne Gore, Službeni list Crne Gore No. 79/08, December 2008.

Strategija odbrane Crne Gore (2019): Vlada Crne Gore, Podgorica, Jun 2019.

Strategijski pregled odbrane (2010): Vlada Crne Gore, Podgorica, Jun 2010.

Tagarev, Todorv (2008): Civilians in Defense Ministries. Connections: The Quarterly Journal 7 (2): 110-117. 
Tahirović, Mehmedin - Injac, Olivera (2016): Development of the Defense System of Montenegro. Contemporary Military Challenges 18 (1): 37-61.

The Slovenia Times (2015): Defence Minister Accused of Abusing Defence Intelligence Service: available at http://www.sloveniatimes.com/defence-minister-accused-of-abusing-defence-intelligence-service (10. May 2020).

United Nations Office on Drugs and Crime (2008): Crime and Its Impact on the Balkans and Affected Countries. Vienna: UN Office on Drugs and Crime.

Vijesti (2019): 'Nevena Nikolić prva crnogorka koja je diplomirala na američkoj vojnoj akademiji West Point': available at https://www.vijesti.me/tv/emisije/nevena-nikolic-prva-crnogorka-koja-je-diplomirala-na-americkoj-vojnoj-akademiji-vest-point (12 October 2019).

Vijesti (2019): 'Poništen tender Ministarstva odbrane vrijedan 310.000 eura: available at: https:// www.vijesti.me/vijesti/ekonomija/ponisten-tender-ministarstva-odbrane-od-310-000-eura (12 May 2020).

Vlada Crne Gore (2007): Zakon o odbrani Crne Gore, Sluzbeni list Crne Gore No. 47/07 (07/08/2077), No. 86/09 (25/12/2009), No. 88/09 (31/12/2009), No. 25/10 (05/05/2009), No. 40/11 (08/08/2011), No. 14/12 (07/03/2012), No.2/17 (10/01/2017).

Vlada Crne Gore (2008): Strategija odbrane Crne Gore, Sluzbeni list Crne Gore No. 75/08., December 2008.

Vlada Crne Gore (2012): Zakon o slobodnom pristupu informacijama, Službeni list Crne Gore No.044/12. (09/08/2012).

Vlada Crne Gore (2016): Zakon o zaštiti I spasavanju, Službeni list Crne Gore No. 013/07 (18/12/2007), No. 005/08 (23/01/2008), No. 086/09 (25/12/2009), No. 032/11 (01/07/2011), No. 054/16 (15/08/2016).

Vlada Crne Gore (2017): Zakon o vojsci Crne Gore, Službeni list Crne Gore No.051/17 (03/08/2017), No. 034/19 (21/06/2019).

Vlada Republike Slovenije (2003): Zakon o parlamentarnem nadzoru obveščevalnih in varnostnih služb, Uradni list RS, št. 26/03 z dne 13. 3. 2003.

Vlada Republike Slovenije (2010): Resolucija o splošnem dolgoročnem programu razvoja in opremljanja Slovenske vojske do leta 2025. Uradni list RS, št. 103/04, z dne 23. 11. 2010.

Vlada RS, Zakon o obrambi (1994): Zakon o obrambi, Uradni list RS, št. 82/94 z dne 30. 12. 1994).

Vuga Beršnak, Janja - Jelušič, Ljubica (2015): The position of the female service members in the Slovenian Armed Forces, in Jakop, Zdravko, ed., Compendium, 90-98, Centre for Security Cooperation (RACVIAC).

Williams, Phil (1994): Transnational Criminal Organisations and International Security. Survival 36 (1): 96-113.

Young, Thomas-Durell (2018): Impediments to Reform in European Post-Communist Defense Institutions: Addressing the Conceptual Divide. Problems of Post-Communism 65 (3): 161-174. 
Iztok Prezelj, PhD is Professor and Vice-Dean for Research at the Faculty of Social Sciences, University of Ljubljana, Kardeljeva ploscad 5, 1000 Ljubljana, e-mail: iztok. prezelj@fdv.uni-lj.si

Olivera Injac, PhD is Associate Professor, Department for Security Studies, University of Donja Gorica, Oktoih 1, 81000 Podgorica, e-mail: olivera.injac@udg.edu.me

Anja Kolak, Msc. is Researcher at the Faculty of Social Sciences, University of Ljubljana, Kardeljeva ploscad 5, 1000 Ljubljana, e-mail: anja.kolak@fdv.uni-lj.si 